\title{
Shan Virus: A New Mimivirus Isolated from the Stool of a Tunisian Patient with Pneumonia
}

\author{
Hanene Saadi ${ }^{a}$ Dorine-Gaelle Ikanga Reteno ${ }^{a}$ Philippe Colson ${ }^{a}$ Sarah Aherfi ${ }^{a}$ \\ Philippe Minodier $^{b}$ Isabelle Pagnier ${ }^{a}$ Didier Raoult ${ }^{a, c}$ Bernard La Scola ${ }^{a}$ \\ aUnité de Recherche sur les Maladies Infectieuses et Tropicales Emergentes (URMITE), Aix-Marseille Université, and \\ bServices des Urgences Pediatriques de l'Hopital Nord, Assistance Publique-Hopitaux de Marseille, Marseille, France; \\ 'Special Infectious Agents Unit, King Abdulaziz University, Jeddah, Saudi Arabia
}

\section{Key Words}

Human stool · Shan virus · Pneumonia

\begin{abstract}
Objective: Following the isolation of a Marseillevirus from the stool of a healthy young Senegalese and a Mimivirus from a Tunisian patient with pneumonia, we attempted to isolate other giant viruses of amoebae from a large human stool collection. Methods: During the period 2010-2011, a total of 1,605 stool samples, including 115 from Tunisian patients with pneumonia, were cultured on amoebae. We used a recently developed high-throughput isolation system to detect amoebae plaque lysis on agar plates; this method allows for the testing of 100 samples per plate per week. The giant virus was identified by sequencing of genes conserved in Megavirales. Results: A single giant virus, called Shan, was isolated from the stool of a Tunisian patient with pneumonia who responded poorly to antibiotics. This virus has an icosahedral shape typical of members of the family Mimiviridae and a size of $640 \pm 10 \mathrm{~nm}$. Phylogenetic analyses showed that Shan virus was classified as a member of Mimivirus lineage $C$ that infects amoebae. Conclusion: Only one isolate was obtained in this study, suggesting that giant viruses of
\end{abstract}

amoebae are rare in human stool. The isolation of Shan virus from a patient with pneumonia brings into question the etiological role of this virus and its subsequent release in stool.

(c) 2013 S. Karger AG, Basel

\section{Introduction}

The nucleocytoplasmic large DNA viruses, recently proposed to be reclassified in the order Megavirales [1], represent a monophyletic group of large and giant viruses. This group comprises six established families of viruses as well as a seventh proposed family, the Marseilleviridae [2-5]. The Megavirales members include viruses that are pathogens of animals and several unicellular eukaryotes $[5,6]$. Their replication cycle occurs either primarily or exclusively in the cytoplasm and, with very few exceptions, is associated with the formation of cytoplasmic virus factories [7-9]. Among the Megavirales, the largest viruses belong to the family Mimiviridae. Mimivirus, the prototype member of this family, has a genome size of $\sim 1.2 \mathrm{Mb}$ and includes more than 1,000 genes predicted to encode for proteins [10]. The majority of currently identified mimiviruses were isolated using the

\begin{tabular}{ll}
\hline KARGER & $\begin{array}{l}\text { ○ 2013 S. Karger AG, Basel } \\
0300-5526 / 13 / 0566-0424 \$ 38.00 / 0 \quad \text { Karger }\end{array}$ \\
E-Mail karger@karger.com & $\begin{array}{l}\text { This is an Open Access article licensed under the terms of the } \\
\text { Creative Commons Attribution-NonCommercial 3.0 Un- } \\
\text { ported license (CC BY-NC) (www.karger.com/OA-license), } \\
\text { applicable to the online version of the article only. Distribu- } \\
\text { tion permitted for non-commercial purposes only. }\end{array}$
\end{tabular}

Prof. Bernard La Scola

Unité de Recherche sur les Maladies Infectieuses et Tropicales Emergentes CNRS UMR 7278, UM63, IRD 198 Inserm 1095, Aix-Marseille Université 27, boulevard Jean-Moulin, FR-13385 Marseille Cedex 05 (France) E-Mail bernard.la-scola@ univ-amu.fr 
freshwater protist Acanthamoeba spp. [11, 12]. The largest known viral strain is Megavirus chiliensis, which belongs to lineage $\mathrm{C}$ of the mimiviruses of amoebae and was isolated from seawater by coculture with Acanthamoeba castellanii [13]. However, the specific host for this virus remains unknown. The discovery of Mimivirus [14] prompted the scientific community to study the possible involvement of this virus in pneumonia [15]. Several studies have been performed to determine the possible involvement of mimiviruses in pneumonia; however, the results have been contradictory [15-20]. Senegalvirus, isolated from the stool of a healthy young Senegalese man, is closely related to but distinct from Marseillevirus, the prototype member of the family Marseilleviridae [21, 22]. Recently, Mimivirus was isolated from the bronchoalveolar lavage of a patient presenting with pneumonia [23]. This was the second strain of giant virus isolated from a human being [23]. A comparison of the Mimivirus genomes demonstrated an important genetic diversity that may explain failures of several studies to detect Mimivirus by PCR using primers specific for Mimivirus only $[16,17,19,20]$. In this present study, we used a highthroughput culture system to study the presence of giant viruses in a collection of French, Senegalese and Tunisian stool samples.

\section{Patients and Methods}

\section{Sample Collection}

The 1,605 human stool samples analyzed in this study included 174 stool samples of children suffering from gastroenteritis and 1,201 stool samples of healthy children. Both sets of samples were collected in la Timone Hospital (Marseille, France) during the period of 2010-2013. During the period of 2010-2012, 115 stools were obtained from Tunisian patients with community-acquired pneumonia (inpatient and outpatient), and 115 samples were obtained from healthy Senegalese between 2008 and 2010 in Dielmo and Ndiop [24]. Written consent was obtained from the patients or a family member. The project was approved by our ethics committee (ref. No. 07-006). Stool samples from France were stored at $-80^{\circ}$. Stool samples from Tunisia were stored at $-20^{\circ}$ and then shipped at $+4^{\circ}$ to Marseille where they were stored at $-80^{\circ}$. Immediately after collection, stool samples from Senegal were shipped at $+4^{\circ}$ to Marseille where they were stored at $-80^{\circ}$. Gastroenteritis in children was defined as the presence of diarrhea, and the diagnosis of pneumonia was defined as described elsewhere [21].

\section{Preparation of Samples}

Stool samples were prepared in the laboratory by adding $10 \mathrm{ml}$ of sterile distilled water followed by centrifugation at 2,000 rpm for $15 \mathrm{~min}$ to remove large particles from the samples. The supernatant was collected and centrifuged at 15,000 rpm for $30 \mathrm{~min}$. The pellet was shaken in $1 \mathrm{ml}$ of sterile Page's amoebal saline (PAS),
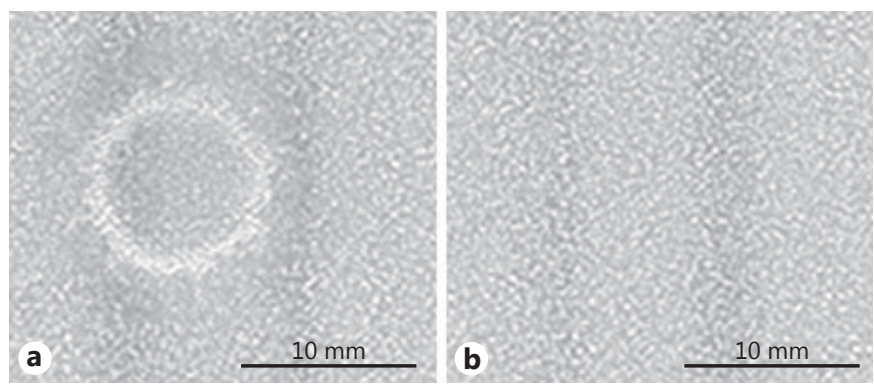

Fig. 1. Lysis plaques under optimal conditions on an agar plate coated with A. polyphaga in the presence of Shan virus: the almost complete disappearance of trophozoites (a) and negative control area, showing trophozoites adherent to the surface of the agar (b).

and an antibiotic mixture containing $10 \mu \mathrm{l}$ of ciprofloxacin $(2 \mathrm{mg} /$ $\mathrm{ml}$; Panpharma, ZI Clairay, France), $10 \mu \mathrm{l}$ of vancomycin $(2 \mathrm{mg}$ / $\mathrm{ml}$; Mylan, Saint-Priest, France), $10 \mu \mathrm{l}$ of colimycine (50 IU/ml; Sanofi Aventis, Paris, France), $10 \mu \mathrm{l}$ of rifampicin $(2 \mathrm{mg} / \mathrm{ml}$; Sanofi Aventis, Paris, France) and $10 \mu \mathrm{l}$ of Fungizone $(10 \mu \mathrm{g} / \mathrm{ml}$; Bristol Myers Squibb, Rueil-Malmaison, France) was added. Subsequently, we performed five successive rinses in PAS buffer to remove the antibiotics. Finally, $300 \mu$ l of each suspension was used for inoculation, and the remaining sample was frozen at $-80^{\circ}$ for further inoculation, DNA extractions and PCR assays.

\section{Amoeba Culture on Agar Plates and Preliminary}

Characterization

The amoeba culturing was performed by preparing agar plates supplemented with antibiotics, depositing a monolayer of amoeba, inoculating a drop $(5-10 \mu \mathrm{l})$ of the viral enrichment supernatant and then observing lysis plaques visible to the naked eye [25]. After lysis was observed, the agar under the plaque was cut, divided into small pieces, suspended in $1 \mathrm{ml}$ of PAS buffer, vortexed and filtered through a $1.2-\mu \mathrm{m}$-pore filter prior to inoculation on fresh amoebae in PAS buffer. The viral suspension was used for virus cloning using an end-point dilution method as previously described $[11,26]$. After fixation with methanol, the initial morphology characterization was performed using Gram, Gimenez and modified MayGrünwald Giemsa staining (Hemacolor ${ }^{\circledR}$; Merck, Darmstadt, Germany). A portion of the viral suspension $(200 \mu \mathrm{l})$ was also prepared for electron microscopy. Finally, after the large-scale production of the virus, DNA was extracted and prepared for whole genome sequencing. The genome was sequenced on an Illumina MiSeq instrument (Illumina Inc., San Diego, Calif., USA). Sequence reads were assembled into 44 contigs using the CLC Bio software (http:// www.clcbio.com/index.php?id = 28). The prediction of proteinencoding genes in the Shan draft genome orthologs using GenemarkS [27] enabled the identification of proteins conserved among the members of the Megavirales. A phylogenetic reconstruction was performed based on a cured concatenated alignment of three out of four of these conserved genes [D5-like helicase-primase (NCVOG0023), DNA polymerase B-family (NCVOG0038), A32like packaging ATPase (NCVOG0249) and A2L-like transcription factor (NCVOG0262)] [4]. Phylogenetic reconstructions were performed using the maximum likelihood method with Mega 5 

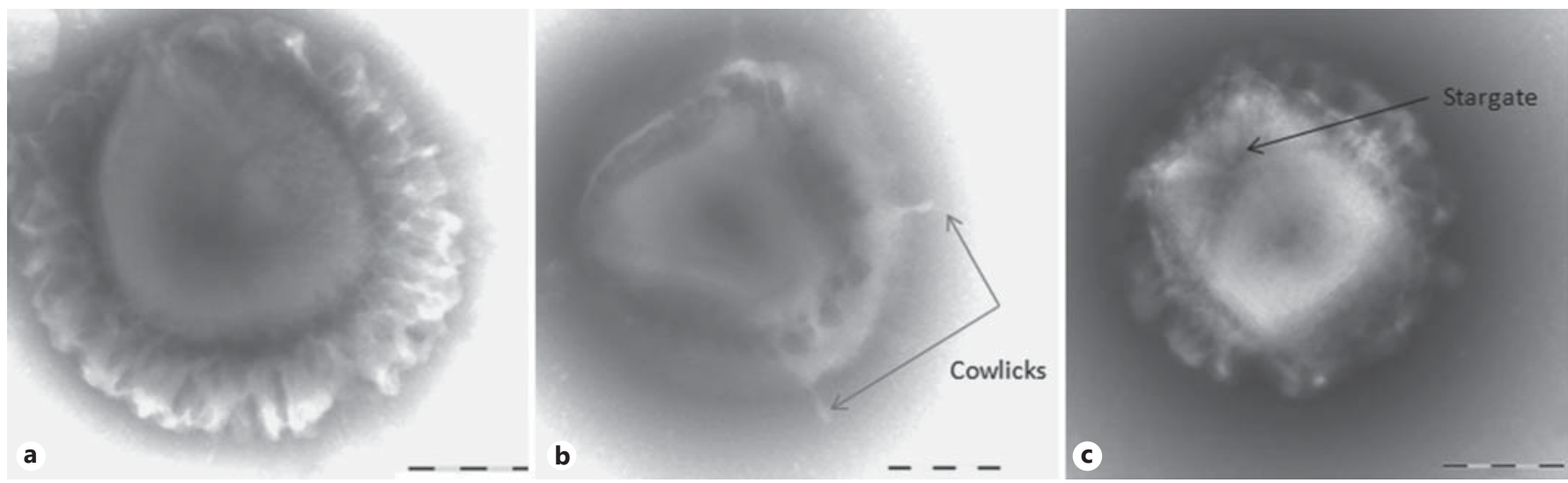

Fig. 2. a TEM image of the isolated virus showing the morphology of a typical Mimiviridae Shan virus particle. b Presence of 'cowlicks' on Shan virus with the typical 'cowlicks' of group C of the Mimiviridae family. c A starfish structure, named 'stargate'.
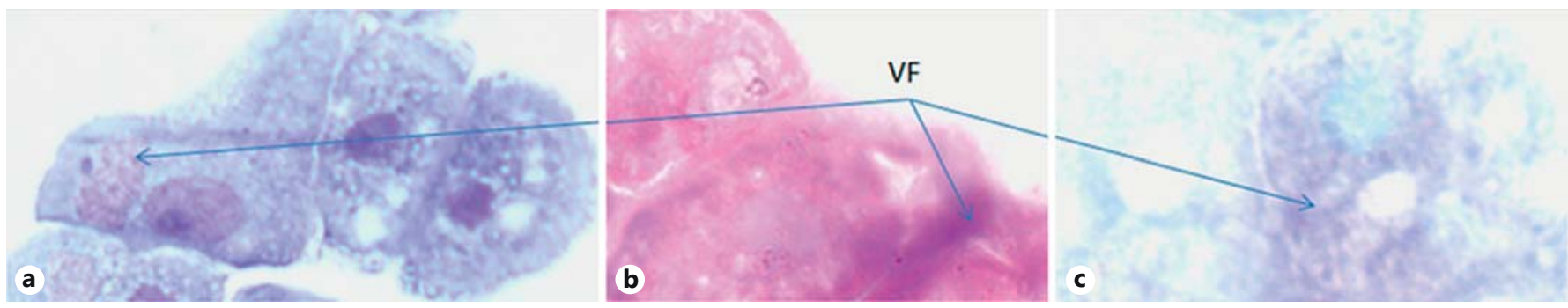

Fig. 3. Hemacolor (a), Gram (b) and Giemnez (c) staining of A. polyphaga infected with Shan virus. Original magnification $\times 1,000$. $\mathrm{VF}=$ Virus factories.

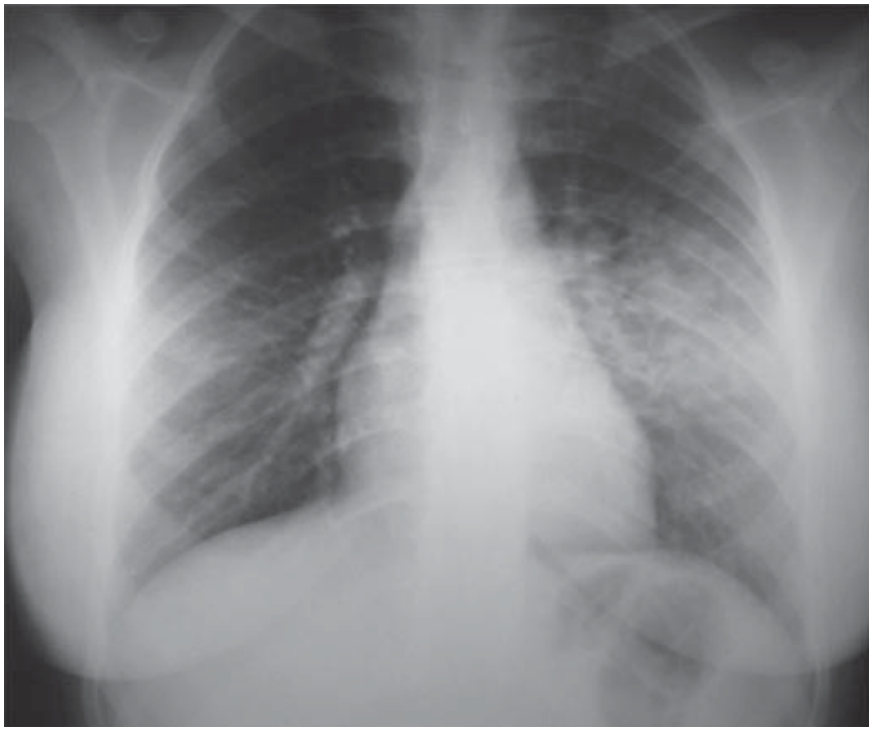

Fig. 4. Chest X-ray of the patient displaying consolidation of the left lower lobe. software [28] after the selection of conserved blocks using Gblocks [29] from the multiple alignment obtained using Muscle software [30]. GenBank accession numbers for sequences used in this analysis are provided in the online supplementary table 1 (see www. karger.com/doi/10.1159/000354564).

\section{Results}

After testing the 1,605 stool samples, we isolated a giant virus, named Shan virus, from 1 of these samples. The surface of lysis plaques for this virus at $12 \mathrm{~h}$ was $\sim 81 \mathrm{~mm}^{2}$ (fig. 1a, b). Electron microscopy showed a Mimivirus-like virion with a size of $640 \pm 10 \mathrm{~nm}$ (fig. 2a), a very dense layer of fibrils with larger tufts ('cowlicks') previously observed in mimiviruses of amoebae of lineage C [13] (fig. 2b), and starfish-shaped structures ('stargates') first identified in Mimivirus [31] (fig. 2c). The presence of Shan viral factories was detected in amoebae using Hemacolor (fig. 3a), Gram (fig. 3b) and Gimenez (fig. 3c) staining at $12 \mathrm{~h}$. The 
Fig. 5. Phylogenetic reconstruction based on an alignment of the amino acid sequences of the major capsid protein (a), the DNA polymerase B family (b) and a cured concatenated alignment of the VV-A32 packaging ATPase and the D5 helicase primase (c), performed using the maximum likelihood method with Mega 5 software (http://www.megasoftware.net/). The maximum likelihood trees are depicted in each case; primases were inferred from 557 , 1,310 and 1,179 amino acid positions, respectively. The probabilities are shown near the branches as a percentage and are used as confidence values for the tree branches. The scale bar represents the number of estimated changes per position for a unit of branch length.

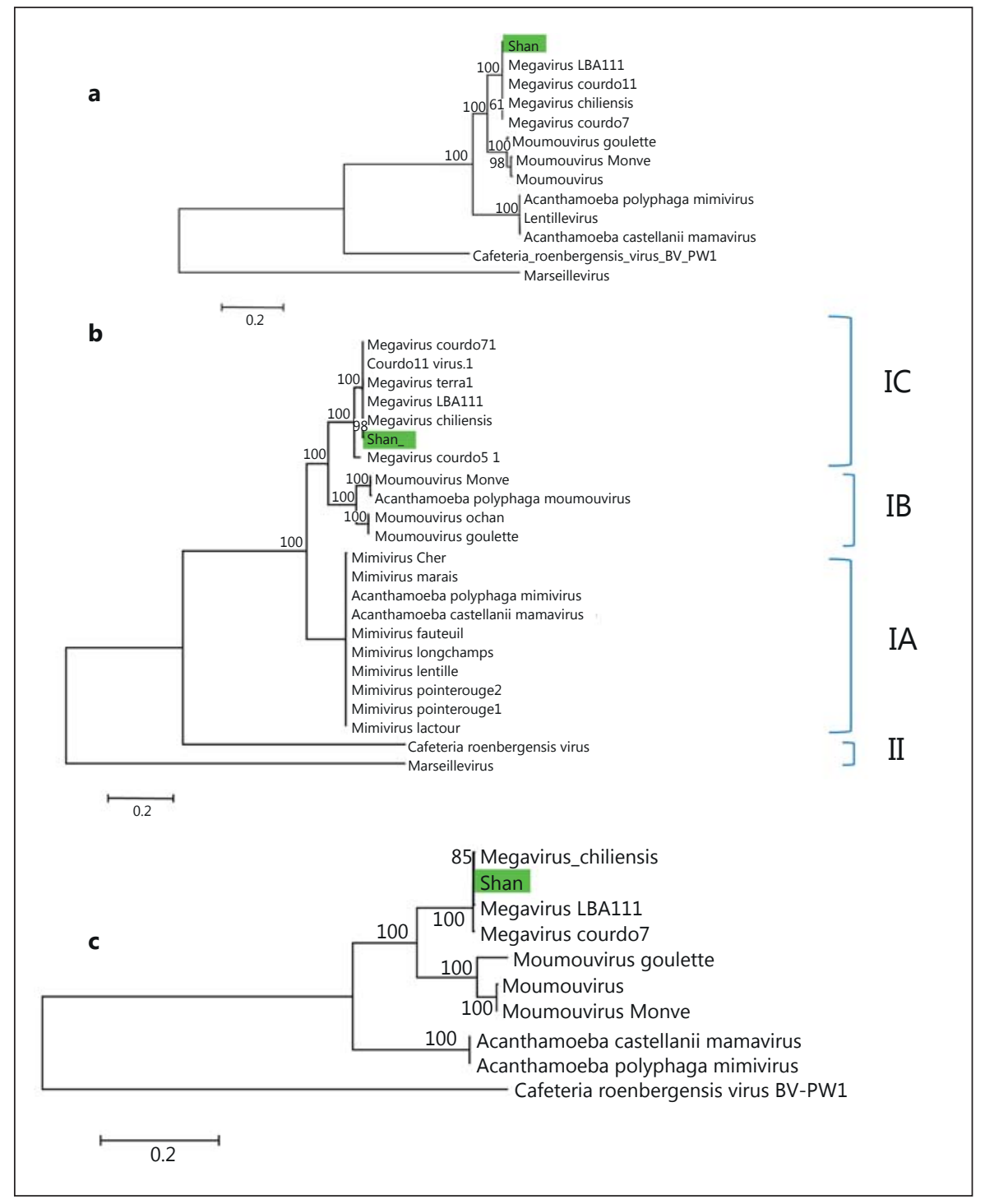

patient from whom Shan virus was obtained was a young 17-year-old girl hospitalized with fever $\left(40^{\circ}\right)$ for 15 days associated with a productive cough. She presented with diarrhea at admission. Chest X-ray showed opacity of the lower left pulmonary field (fig. 4). She had a leukocytosis $\left(11,910 / \mathrm{mm}^{3}\right)$ and an increased erythrocyte sedimentation rate $(32 \mathrm{~mm}$ at the first hour). Other etiological investigations by blood culture and standard culture after bronchoscopy did not find any etiologic agent. Stool culture did not provide evidence of any enteropathogenic bacterium. Finally, the patient was treated with amoxicillin for 10 days, and she showed a slow clinical and radiological improvement but recovered without any recurrence. Unfortunately, we were unable to obtain a respiratory or serum sample from the patient. The phylogenetic analysis of a concatenated alignment of conserved Mimivirus genes and BLASTp searches for orthologous proteins with the best matches in the NCBI GenBank non-redundant protein sequence database showed that Shan virus is a bona fide new member of lineage $\mathrm{C}$ of amoebae-associated mimiviruses and is very closely related to $M$. chiliensis (fig. 5).

\section{Discussion}

In this work, we isolated for the first time a strain of Mimivirus from human feces. This stool sample was collected from a Tunisian girl suffering from pneumonia. 
Shan is the second giant virus of amoeba isolated from human stool after the isolation of a strain of Marseillevirus from a young healthy Senegalese $[22,23]$. Another closely related Mimivirus, LBA11, was isolated from the bronchoalveolar fluid of a young Tunisian woman with pneumonia [21]. The isolation of the Shan giant virus from among 1,518 stool samples demonstrates that our high-throughput strategy is effective in allowing the parallel testing of several hundred samples. From these data, we conclude that mimiviruses are not responsible for gastrointestinal infections. This result was unexpected because we previously identified several Mimivirus- and Marseillevirus-like sequences in stool samples from humans using a metagenomic approach [23]. It is likely that these viruses are more broadly distributed than was initially expected and that they can have hosts other than the Acanthamoeba spp. used for their coculture. For example, the virus most closely related to Mimivirus is Cafeteria roengbergensis virus, which grows in a unicellular marine biflagellate [32].

The isolation of Shan virus from a Tunisian girl provides evidence of its role in pneumonia in Tunisia. From our collection of 1,518 stool samples, only 115 samples from Tunisian patients with pneumonia were initially analyzed with the goal of isolating Mycobacterium tuberculosis as described previously in our laboratory [33]. Following the first description of a Tunisian patient with pneumonia associated with the isolation of a giant virus in bronchoalveolar lavage [21], the incidental isolation of this giant virus has led to further suspicion regarding the prevalence of giant viruses in pneumonia patients in $\mathrm{Tu}$ nisia $[23,34]$. Unfortunately, it was not possible to test sera or obtain a frozen respiratory sample for this patient to provide a more comprehensive evaluation.

In our study, we did not find evidence that giant viruses of amoebae could be an agent of gastroenteritis, nor that they are common in the stools of French children or Senegalese adults, although a greater number of samples could have been tested. The isolation of this second strain from a human with pneumonia provides evidence of a potentially high prevalence of these viruses in pneumonia and/or high frequency of such viral infection in Tunisian patients.

\section{Acknowledgments}

We thank the Programme Hospitalier de Recherche Clinique for the financial support of this clinical research project on human emerging diseases.

\section{Disclosure Statement}

The authors declare that there is no potential conflict of interest or financial disclosure.

\section{References}

1 Colson P, de Lamballerie X, Fournous G, Raoult D: Reclassification of giant viruses composing a fourth domain of life in the new order Megavirales. Intervirology 2012;55: 321-332.

$\checkmark 2$ Iyer LM, Aravind L, Koonin EV: Common origin of four diverse families of large eukaryotic DNA viruses. J Virol 2001;75:1172011734.

3 Iyer LM, Balaji S, Koonin EV, Aravind L: Evolutionary genomics of nucleo-cytoplasmic large DNA viruses. Virus Res 2006;117:156184.

4 Yutin N, Wolf YI, Raoult D, Koonin EV: Eukaryotic large nucleo-cytoplasmic DNA viruses: clusters of orthologous genes and reconstruction of viral genome evolution. Virol J 2009;6:223.

-5 Koonin EV, Yutin N: Origin and evolution of eukaryotic large nucleo-cytoplasmic DNA viruses. Intervirology 2010;53:284-292.

6 Yutin N, Koonin EV: Hidden evolutionary complexity of nucleo-cytoplasmic large DNA viruses of eukaryotes. Virol J 2012;9:161.
7 Netherton CL, Wileman T: Virus factories, double membrane vesicles and viroplasm generated in animal cells. Curr Opin Virol 2011;1:381-387.

8 de Castro IF, Volonte L, Risco C: Virus factories: biogenesis and structural design. Cell Microbiol 2013;15:24-34.

-9 Van Etten JL, Dunigan DD: Chloroviruses: not your everyday plant virus. Trends Plant Sci 2012;17:1-8.

10 Raoult D, Audic S, Robert C, Abergel C, Renesto P, Ogata H, La Scola B, Suzan M, Claverie JM: The 1.2-megabase genome sequence of Mimivirus. Science 2004;306:1344-1350.

11 La Scola B, Campocasso A, N’Dong R, Fournous G, Barrassi L, Flaudrops C, Raoult D: Tentative characterization of new environmental giant viruses by MALDI-TOF mass spectrometry. Intervirology 2010;53:344-353.

12 Pagnier I, Reteno D-GI, Saadi H, Boughalmi M, Gaia M, Slimani M, Ngounga T, Bekliz M, Colson P, Raoult D, La Scola B: A decade of improvements in mimiviridae and marseilleviridae isolartion from amoeba. Intervirology 2013;56:354-363.
13 Arslan D, Legendre M, Seltzer V, Abergel C, Claverie JM: Distant Mimivirus relative with a larger genome highlights the fundamental features of Megaviridae. Proc Natl Acad Sci USA 2011;108:17486-17491.

-14 La Scola B, Audic S, Robert C, Jungang L, de Lamballerie X, Drancourt M, Birtles R, Claverie JM, Raoult $\mathrm{D}$ : A giant virus in amoebae. Science 2003;299:2033.

15 La Scola B, Marrie TJ, Auffray JP, Raoult D: Mimivirus in pneumonia patients. Emerg Infect Dis 2005;11:449-452.

16 Dare RK, Chittaganpitch M, Erdman DD: Screening pneumonia patients for Mimivirus. Emerg Infect Dis 2008;14:465-467.

-17 Larcher C, Jeller V, Fischer H, Huemer HP: Prevalence of respiratory viruses, including newly identified viruses, in hospitalised children in Austria. Eur J Clin Microbiol Infect Dis 2006;25:681-686.

18 Vanspauwen MJ, Franssen FM, Raoult D, Wouters EF, Bruggeman CA, Linssen CF: Infections with Mimivirus in patients with chronic obstructive pulmonary disease. Respir Med 2012;106:1690-1694. 
19 Costa C, Bergallo M, Astegiano S, Terlizzi ME, Sidoti F, Solidoro P, Cavallo R: Detection of Mimivirus in bronchoalveolar lavage of ventilated and nonventilated patients. Intervirology 2012;55:303-305.

20 Arden KE, McErlean P, Nissen MD, Sloots TP, Mackay IM: Frequent detection of human rhinoviruses, paramyxoviruses, coronaviruses, and bocavirus during acute respiratory tract infections. J Med Virol 2006;78:12321240.

21 Lagier JC, Armougom F, Million M, Hugon P, Pagnier I, Robert C, Bittar F, Fournous G, Gimenez G, Maraninchi M, Trape JF, Koonin EV, La Scola B, Raoult D: Microbial culturomics: paradigm shift in the human gut microbiome study. Clin Microbiol Infect 2012;18:1185-1193.

22 Colson P, Fancello L, Gimenez G, Armougom F, Desnues C, Fournous G, Yoosuf N, Million M, La Scola B, Raoult D: Evidence of the megavirome in humans. J Clin Virol 2013;57 191-200.

-23 Saadi H, Pagnier I, Colson P, Kanoun Cherif J, Beji M, Boughalmi M, Azza S, Armstrong N, Robert C, Fournous G, La Scola B, Raoult D: First isolation of Mimivirus in a patient with pneumonia. Clin Infect Dis 2013; 57:e127-e134.
24 Fenollar F, Trape JF, Bassene H, Sokhna C, Raoult D: Tropheryma whipplei in fecal samples from children, Senegal. Emerg Infect Dis 2009;15:922-924.

$>25$ Boughalmi M, Saadi H, Pagnier I, Colson P, Fournous G, Raoult D, La Scola B: Highthroughput isolation of giant viruses of the Mimiviridae and Marseilleviridae families in the Tunisian environment. Environ Microbiol 2013;15:2000-2007.

26 Boyer M, Yutin N, Pagnier I, Barrassi L, Fournous G, Espinosa L, Robert C, Azza S, Sun S, Rossmann MG, Suzan-Monti M, La Scola B, Koonin EV, Raoult D: Giant Marseillevirus highlights the role of amoebae as a melting pot in emergence of chimeric microorganisms. Proc Natl Acad Sci USA 2009;106: 21848-21853.

27 Besemer J, Borodovsky M: GeneMark: web software for gene finding in prokaryotes, eukaryotes and viruses. Nucleic Acids Res 2005; 33:W451-W454.

28 Tamura K, Peterson D, Peterson N, Stecher G, Nei M, Kumar S: MEGA5: molecular evolutionary genetics analysis using maximum likelihood, evolutionary distance, and maximum parsimony methods. Mol Biol Evol 2011;28:2731-2739.

29 Castresana J: Selection of conserved blocks from multiple alignments for their use in phylogenetic analysis. Mol Biol Evol 2000;17: 540-552.
30 Edgar RC: MUSCLE: multiple sequence alignment with high accuracy and high throughput. Nucleic Acids Res 2004;32:17921797.

1 Suzan-Monti M, La Scola B, Barrassi L, Espinosa L, Raoult D: Ultrastructural characterization of the giant volcano-like virus factory of Acanthamoeba polyphaga Mimivirus. PLoS One 2007;2:e328.

32 Fischer MG, Allen MJ, Wilson WH, Suttle $\mathrm{CA}$ : Giant virus with a remarkable complement of genes infects marine zooplankton. Proc Natl Acad Sci USA 2010;107:1950819513.

33 Bonnave PE, Raoult D, Drancourt M: Gastric aspiration is not necessary for the diagnosis of pulmonary tuberculosis. Eur J Clin Microbiol Infect Dis 2013;32:569-571.

34 Colson P, La Scola B, Raoult D: Giant viruses of amoebae as human pathogens. Intervirology 2013;56:376-385. 